\title{
Improving the efficiency of the production process using SMED
}

\author{
Bożena Skotnicka-Zasadzień ${ }^{1}$, Radosław Wolniak ${ }^{2}$, and Anna Gębalska-Kwiecieńn ${ }^{3}$ \\ ${ }^{1}$ Silesian University of Technology, Organisation and Management Faculty, 41-800 Zabrze Roosvelta \\ Str., Poland \\ ${ }^{2}$ Silesian University of Technology, Organisation and Management Faculty, 41-800 Zabrze Roosvelta \\ Str., Poland \\ ${ }^{3}$ Silesian University of Technology, Organisation and Management Faculty, 41-800 Zabrze Roosvelta \\ Str., Poland
}

\begin{abstract}
The article presents one of the methods of management used in quality engineering, i.e. the SMED, which is applied to streamline the functioning of machines used on a production line. The research problem that was analysed on one of the production lines was too long a retooling time which resulted in too high a cost of the operation which, consequently, resulted in excessive overall production costs. The main aim of the actions undertaken when applying the SMED method was to identify potentially problematic areas and reduce the retooling time. All those actions allowed to minimise production costs, and improved the functioning of the company as well as the efficiency of the production process.
\end{abstract}

\section{Theoretical introduction}

Due to market requirements and the need to reduce constantly rising production costs, enterprises more and more often introduce solutions of the Lean methodology. The Lean concept, which originates from Japan, also referred to as „lean management”, consists mainly of getting rid of all the wastefulness in a company. Wastefulness refers to activities such as overproduction, unnecessary movements, stocks, unnecessary transport, any errors in the production process, as well as waiting times and shortages. To achieve the intended benefits, it is necessary to implement many Lean tools and methods $[1,2,7]$.

For the proper functioning of the company and a quick response to the needs of customers, it is necessary to introduce shorter production series, which in turn leads to shortening retooling times and reducing production costs. To achieve such goals, the Single Minute Exchange of Die method, or SMED, is used [3, 8, 10, 11, 22].

The SMED method developed by a Japanese engineer Shigeo Shingo, was first implemented in TOYOTA's factories. The SMED methodology was established to reduce the time needed for retooling of the press and setting tools in machines, but its philosophy can be applied to all production processes. It allows to reduce some of the retooling times from several hours down to several minutes, which it is very important when it comes to reducing production costs. Sometimes shortening even one operation allows for the reduction of costs on the whole production line. It is known that achieving a result below 
10 minutes is not always possible for all retoolings, but the very application of the method reduces the retooling time in virtually any case. Any reduction of retooling time will consequently reduce costs $[4,9,12]$.

The retooling processes of machines and devices have a characteristic common feature, namely they all consist of four stages that are the same for each type of equipment and operation. The first stage is preparation, inspection of parts and tools as well as postprocess regulations $[5,6,13,15]$. The second stage consists of assembly and disassembly of blades, parts and tools. Then settings, measurements and calibrations are made. The final stage is trial series and corrections of the machine settings [14, 16, 18, 19, 21]. The scientific goal in this article was to show how the application of the SMED method and the introduction of improvement measures have an impact on improving the efficiency of the production process.

\section{Description of the research problem}

In the company surveyed, the main problem was related to the retooling of machines used for pipe bending. The total retooling time of this machine was 116 minutes, which is much too long, which resulted in generating large losses and reducing the efficiency of the production process. In addition to the very long retooling time of the machine, the following factors were also important: the machine is heavily used and plays a very important role in the whole production process. It is the most expensive and most complex machine in the whole production hall, with the largest number of retooling, having the most complicated retooling process due to the largest number of parts to be replaced and has the longest downtimes.

All these aspects caused the management to make the decision to deal with the retooling process in the first place with the goal to shorten this time to about 10 minutes. All the activities that were undertaken were consistent with the SMED terminology $[17,20]$.

\section{Measures to improve the efficiency of the production process}

In order to improve the efficiency of the production process, the following actions were taken in accordance with the SMED terminology:

- preparation and analysis of a video recording, the checklist presented in Table 1 was helpful in the analysis

- $\quad$ specifying all the activities performed during the retooling that generate the greatest losses of time. These included: searching for tools, importing tools for retooling the machine, organizing the trolley with tools, consulting, loading tools onto the trolley. The total time of all activities is 125 [17]

- division of internal to external activities

- transforming internal activities into external ones

- $\quad$ proposing and implementing improvement measures.

Table 1. Control checklist prior to implementing SMED [17].

\begin{tabular}{|c|l|l|l|}
\hline \multicolumn{2}{|c|}{$\begin{array}{c}\text { Control Checklist } \\
\text { Prior to SMED }\end{array}$} & Process & Machine No. \\
\cline { 2 - 3 }$\#$ & \multicolumn{1}{c|}{ Production line } & Checkpoint & Notes \\
\hline 1 & $\begin{array}{l}\text { Is there a full set of the necessary tools and equipment available at } \\
\text { the station? }\end{array}$ & \\
\hline 2 & $\begin{array}{l}\text {.Are the tools and equipment easily accessible to the operator during } \\
\text { the entire retooling process? }\end{array}$ & \\
\hline 3 & Are the tools and equipment arranged in the order in which they are & \\
\hline
\end{tabular}




\begin{tabular}{|c|l|l|}
\hline & used during retooling ? & \\
\hline 4 & $\begin{array}{l}\text { Is putting the tools and equipment back in their place a common } \\
\text { practice ? }\end{array}$ & \\
\hline 5 & Are special carts used and is there a designated location for them ? & \\
\hline 6 & Is placing thing on the special carts a common practice? & \\
\hline 7 & Does every machine have its retooling instructions ? & \\
\hline 8 & $\begin{array}{l}\text { Are the operators who perform the retooling trained according to the } \\
\text { retooling instructions? }\end{array}$ & \\
\hline 9 & Have quality standards been defined for every product? & \\
\hline 10 & Are the standards placed on every machine? & \\
\hline 11 & Are green standards prepared for every reference? & \\
\hline 12 & Are green standards on display near the relevant machine? & $\begin{array}{l}\text { Are measurement tools located in the right place near the machine } \\
\text { that is being used? }\end{array}$ \\
\hline 13 & Are measurement tools easily accessible to the user? & \\
\hline 15 & Is the proper placement of measurement tools common practice? & \\
\hline 16 & Is the location in which tools and equipment should be stored after & \\
\hline 17 & $\begin{array}{l}\text { Is the location in which tools and equipment should be stored prior to } \\
\text { retooling clearly specified? }\end{array}$ & \\
\hline 18 & Is there a designated location for tools for the next reference? & \\
\hline
\end{tabular}

Among the stages described above, the most important was the preparation and analysis of the video recording, as it was used to identify further activities related to the identification of activities, division into internal and external activities and the process of transforming internal activities into external ones. These were key activities because they allowed to identify the bottleneck which, undoubtedly, was the production machine analysed. Meanwhile, in the case of other machines, no action was taken, as they were carried out in accordance with the standards and were within the limits of 5 - 9 minutes [17].

As it turned out, the introduction of appropriate improvement measures in the form of replacing the manual key with a pneumatic wrench made it possible to shorten the screwing and unscrewing time by as much as $75 \%$. All these aspects caused the retooling time of the line to be reduced by $50 \%$, and the machine which was causing the greatest time losses by almost $60 \%$, Table 2 [17].

Table 2. Retooling control checklist [17].

\begin{tabular}{|c|c|c|c|c|c|}
\hline \multicolumn{6}{|c|}{ RETOOLING CONTROL CHECKLIST } \\
\hline \multicolumn{6}{|c|}{ Setter's name } \\
\hline \multicolumn{3}{|c|}{$\begin{array}{l}\text { Before starting work in my area I have checked the following } \\
\text { elements }\end{array}$} & OK & NOK & NOTES \\
\hline 1 & TOOLS & $\begin{array}{l}\text { Check the completeness of the } \\
\text { toolset }\end{array}$ & & & \\
\hline 1.1 & & Roll/Roll + roller & & & \\
\hline 1.2 & & $\begin{array}{l}\text { Pressure clamp/Clamp with adapter } \\
+ \text { roller/rollers }\end{array}$ & & & \\
\hline 1.3 & & $\begin{array}{l}\text { Smoothening clamp with handles } \\
\text { and hooks }\end{array}$ & & & \\
\hline 1.4 & & Hooves with sliders & & & \\
\hline 1.5 & & Transport clamps & & & \\
\hline 1.6 & & $\begin{array}{l}\text { Mandrel (assembled, complete, in } \\
\text { standard size) }\end{array}$ & & & \\
\hline 1.7 & & Roller pin & & & \\
\hline 1.9 & & $\begin{array}{l}\text { Calibrating tool (with pins and } \\
\text { rings) }\end{array}$ & & & \\
\hline
\end{tabular}




\begin{tabular}{|c|l|l|l|l|l|}
\hline 1.10 & & Screws with washers & & & \\
\hline 2.1 & LUBRICATING & $\begin{array}{l}\text { Check for presence of the "Prolube } \\
\text { amber" lubricant }\end{array}$ & & & \\
\hline 2.2 & & $\begin{array}{l}\text { Check the quality of calibrating } \\
\text { tool lubrication }\end{array}$ & & & \\
\hline 3.1 & $\begin{array}{l}\text { TECHNICAL } \\
\text { DOCUMENTATION }\end{array}$ & $\begin{array}{l}\text { Check if there is technical } \\
\text { documentation }\end{array}$ & & & \\
\hline 3.2 & & $\begin{array}{l}\text { Familiarise yourself with the } \\
\text { technical documentation }\end{array}$ & & & \\
\hline
\end{tabular}

\section{Conclusion}

The presented analysis, consistent with the SMED methodology, allowed to improve the efficiency of the production process by:

- $\quad$ shortening the retooling time of the line by $50 \%$,

- $\quad$ shortening the retooling time of the bending machine by less than $60 \%$,

- reducing the screwing and unscrewing time by $75 \%$,

- $\quad$ shortening the machine part replacement time by almost $32 \%$,

- planned return on investment in the purchase of electric impact wrenches at the level of almost $7 \%$.

In addition to shortening the retooling time, the following actions have been proposed to improve the retooling process [17]:

- permanently affixing handles to the smoothening clamp and temporarily mounting the handles on the roll - external operation,

- $\quad$ mounting of the positioning screw to the pressure clamp and setting the clamp height external operation,

- $\quad$ using a pneumatic wrench to eliminate time wastage during the screwing/unscrewing of a large number of screws with multi-start threads,

- development of a new retooling instruction,

- development of a checklist for setters,

Achieving the results presented was possible by introducing changes in the area of improving the retooling process as well as organization and communication in the workplace [17].

\section{References}

1. J. Sitko, Syst. Wspomag. Inż. Prod., 4, 90 (2016)

2. M. Nowicka-Skowron, R. Ulewicz, 25TH Anniversary International Conference of Metallurgy and Materials, 1962-1997 (2016)

3. A. Zakrzewska-Bielawska, Metody zarzadzania procesami w świetle studiów i badań empirycznych (Uniwersytet Ekonomiczny w Krakowie, Kraków, 2009)

4. S. Kowal, K. Knop, Zeszyty Naukowe Quality. Production. Improvememt, 2, 7 (2017)

5. J.P. Womack, D.T. Jones, Centrum Informacji Menadżera (Warszawa, 2001)

6. M. Kruczek, Z. Żebrucki, Logistyka, 2 (2012)

7. J. Maciak, Komputerowo zintegrowane zarzadzanie - tom II (Zakopane (2011)

8. R. Wolniak, Business and management, 5, 1093 (2017).

9. R. Wolniak, B. Skotnicka-Zasadzień, M. Zasadzień, 3rd International Conference on Social, Education and Management Engineering (SEME, Shanghai, 2017)

10. S. Shigeo, Productivity (Inc,1985) 
11. R. Wolniak, B. Skotnicka-Zasadzień, Metalurgija, 4, 709 (2014)

12. E. Milewska, Business and Management 5, 599-606 (2017)

13. M. Zasadzień, 6th International Conference on Operations Research and Enterprise Systems (ICORES, Porto, Portugal (2017)

14. K. Antosz, A. Pacana, D. Stadnicka, W. Zielecki, (Oficyna Wydawnictwa Politechniki Rzeszowskiej, Rzeszów 2015)

15. B. Szczęśniak, Business and management, 5, 565-572 (2017)

16. J. Brodny, K. Stecuła, M. Tutak, Science and technologies in geology, 65 (2016)

17. M. Ziółkowska, Doskonalenie procesu produkcyjnego przy wykorzystaniu metody SMED w wybranym przedsiębiorstwie produkcyjnym (master thesis on supervising B. Skotnicka-Zasadzień, Zabrze, 2018)

18. J. Baran, International Business Information Management Association, Education Excellence and Innovation Management through Vision 2020: From Regional Development Sustainability to Global Economic Growth (Vienna, Austria 2017)

19. J. Sitko, K. Michalski, 17th International Multidisciplinary Scientific GeoConference. SGEM 2017, Ecology, economics, education and legislation (Albena, Bulgaria (2017)

20. D. Klimecka-Tatar, Production Engineering Archives, 17, 40-44 (2018)

21. R. Ulewicz, International Conference on the Path Forward for Wood Products: A Global Perspective Location (Baton Rouge, 2016)

22. M. Ingaldi, S.T. Dziuba, 24 $4^{\text {th }}$ International Conference on Metallurgy and Materials, (Brno, Czech Rep., 2015) 